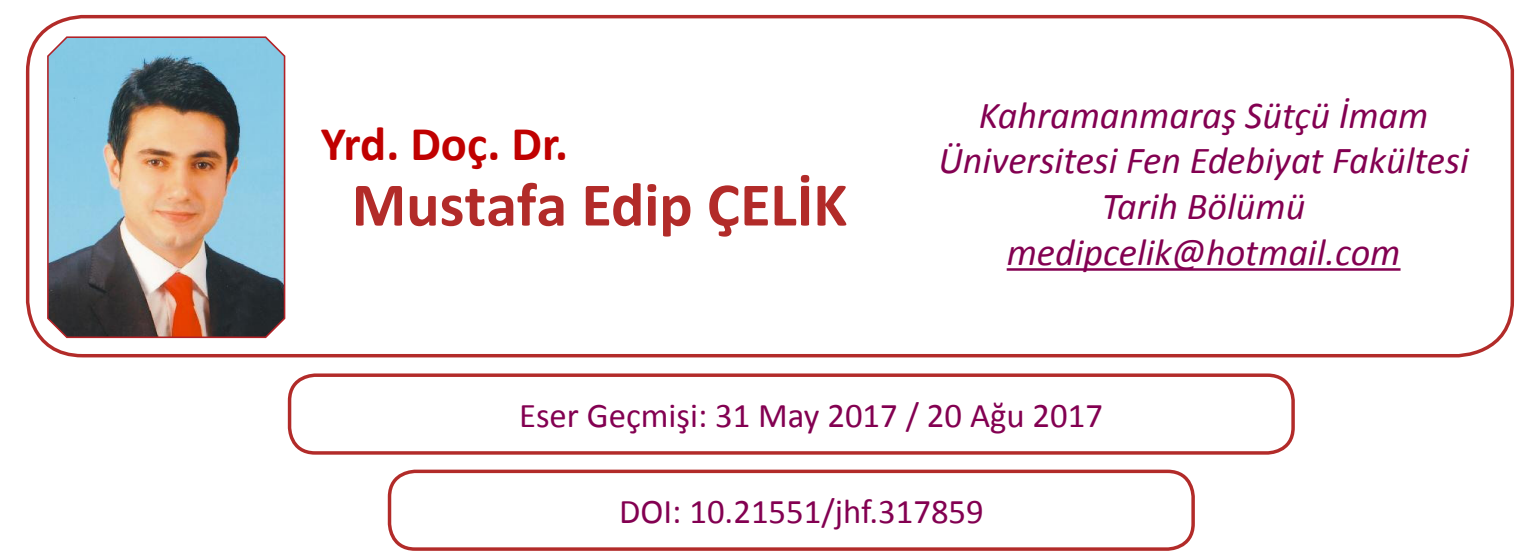

\title{
İngiliz Büyükelçilik Yıllık Raporlarında Türk Diş Politikası (1933-1937)
}

\section{Turkish Foreign Policy in The Annual Reports Of The British Embassy (1933-1937)}

\section{ÖZET}

İngiliz Büyükelçileri, her yılın sonunda bulundukları ülke hakkında yıl içerisinde meydana gelen gelişmeleri, elçilik uzmanları vasıtasıyla rapor halinde Birleşik Krallık hükümetine sunmaktaydı. 1933-1937 yılları arasında Türkiye'nin Ankara Büyükelçisi olarak görev yapan Sir Percy Loraine de, Türkiye ile ilgili raporlar hazırlatarak Birleşik Krallık hükümetine sunmuştur. Bu çalışma 1933-1937 yıllarında Birleşik Krallık Ankara Büyükelçiliğinin Türkiye ile ilgili raporlarında Türk dış politikasının ne şekilde ele alındığını incelemeyi amaçlamaktadır.

Anahtar Kelimeler: Türkiye, Dış Politika, Büyükelçilik Raporları

\section{ABSTRACT}

At the end of each year, the British Ambassadors reported to the UK government a report on the developments that had taken place during that year. Sir Percy Loraine, who served as Turkey's ambassador to Ankara between 1933-1937, also prepared reports on Turkey and presented it to the UK government. This study aims to examine how Turkish foreign policy is addressed in the Annual Reports of the Ankara Embassy of the United Kingdom of Turkey in 1933-1937 on Turkey.

Key Words: Turkey, Foreign Policy, Annual Reports 


\section{Giriş}

I

ngiliz Büyükelçiliğinin hazırladığı yıllık raporlar aracılığıyla, Türkiye'de meydana gelen gelişmeler, Birleşik Krallık hükümetine bildirilmekteydi. Raporlar, İngiliz Büyükelçiliğindeki çalışanlar tarafından uzmanlık alanlarına göre ele alındıktan sonra İngiliz Büyükelçisi tarafından incelenerek bir araya getirilip, Birleşik Krallık Hükümetine sunulmaktaydı. 1937-1933 yıllarının raporları ise bu tarihlerde Birleşik Krallı̆̆ın Ankara Büyükelçiliği görevini sürdüren Sir Percy Loraine tarafından ülkesine sunulmuştur.

1933-1939 yılları arasında İngiltere'nin Ankara büyükelçisi olarak görev yapan Sir Percy Loraine, daha önce üç süreyle Mısır ve Sudan'a Lord Llyod'un yerine Yüksek Komiser olarak görevlendirilmesine kadar Yunanistan'da görev yapmıștır. 1932 yılında Türkiye ile Mısır arasında baş gösteeren “fes krizi”nde, Kahire Yüksek Komiseri olan Sir Percy Loraine'in olumlu çabaları Mısır Hükümeti üzerinde etkili olmuş ve Türkiye’ye verilen notanın yumuşatılmasını sağlamıştır. 1933 yılında Ankara'da göreve başlayan Loraine, yine 19041907 yılları arasında ilk dış görev olarak İstanbul ataşeliğine atanmıştır. ${ }^{1}$ Loraine'in 1904'teki ilk görev yerinin Türkiye olması ve "fes krizi"nde olumlu tavır takınması Türkiye'de sıcak karşılanmasını sağlayan etkenler olmuştur.

Türkiye açısından dış politikada büyük önem taşıyan Atatürk dönemi dış politikasını kapsayan 1930 sonrası dönemde, dıș politikanın belirleyicisi Mustafa Kemal Atatürk, uygulayıcısı ise 13 yıl Dışişleri Bakanlığı yapan ve Türk dış politikasının mimarlarından biri olan Tevfik Rüştü Aras olmuştur². Türkiye, 1930 sonrası dönemde daha etkili bir dış politika izlemeye başlamış ve bu dönemde meydana gelen olaylar İngiltere ile yakınlaşmasını sağlamıștır. Özellikle 1933 yılı itibariyle Almanya'nın silahlanması ve İtalya'nın saldırgan tutumu İngiltere için Türkiye'yi daha da önemli bir ülke haline getirmiştir. Dolayısıyla İkinci Dünya Savaşı'na giden bu süreçte Birleşik Krallığın Ankara büyükelçiliğinin Türk dış politikasını takibi ve ne şekilde değerlendirdiği önem arz etmektedir.

Bu dönemde Türk dış politikasında meydana gelen önemli gelişmeler Balkan Paktı, Montrö Boğazlar Sözleşmesi ve Sadabad Paktı gibi Türkiye’nin güvenliğini ilgilendiren konular olmuştur. Türkiye'nin girmiş olduğu bu paktlar Atatürk'ün "Yurtta Sulh, Cihanda Sulh" ilkesi doğrultusunda gerçekleşmiştir. Atatürk'ün dış politikada ki bu ilkesi, bağımsızlık ve ortak güvenliğe dayanmaktadır. Tevfik Rüştü Aras'da bu prensibin aslında sosyalist bir görüşü ifade ettiğini belirtmektedir ${ }^{3}$. Türkiye çevresini imzalamış olduğu paktlarla birlikte güvence altına almak isterken, kolektif bir barış anlayışı ile de dünya barışına katkı sağlamak istemiştir. Bu süreçte İngiltere'nin I. Dünya Savaşı sonrası oluşturduğu statükoyu devam ettirebilmek adına dünya barıșını sağlamak istemesi ve bu yönde politika geliștirmesi, Türkiye'nin de

1 Hikmet Özdemir, Atatürk'ün Ardından Sir Percy Loraine'in Tanıklı̆ı, Remzi Kitabevi, İstanbul 2010, s. 13,14

2 Tevfik Rüş̧ü Aras, Atatürk'ün Dış Politikası, Kaynak Yayınları, İstanbul 2010, s. 7

3 Aras, a.g.e, s. 9 
İngiltere’nin bu politikasını kendisi için fırsata çevirmek istemesi, İngiltere ile Türkiye’yi yakınlaştıran bir unsur olmuştur.

Uygulamak istediği dış politika ile bölgesinde etkin bir rol oynama gayreti içerisinde olan Türkiye, dönemin önemli gücü olan ve özellikle 1935 sonrasında Türkiye’nin stratejik konumundan faydalanmak isteyen İngiltere ile sıkı bir ilişki içerisine girmiştir. Türkiye, dış politikasında atmış olduğu adımların birçoğunda, İngiltere ile görüş alışverişinde bulunmuştur. Almanya ve İtalya'nın izlediği politikalar nedeniyle savaş tehditlerinin artmış olduğu dönemde, Balkanlardan Ortadoğu'ya uzanan bir güvenlik köprüsü oluşturmak isteyen İngiltere açısından Türkiye konumu itibariyle büyük önem arz etmekteydi. Bu yüzden, İngiltere oluşturulan bu güvenlik paktlarının yakından takipçisi ve destekleyicisi olmuştur. Türkiye bu süreçte İngiltere merkezli batı ile daha da yakınlaşırken, eski dostu Sovyet Rusya ile olan münasebetlerine herhangi bir zarar gelmemesi adına uğraş vermişse de Montrö Boğazlar Sözleşmesi ile birlikte yaşanan gelişmeler Türk-Sovyet ilişkilerine olumsuz yansımıştır.

\section{Balkan Paktı Öncesi Türk Dış Politikası}

İngiliz Büyükelçilik raporlarında, Türkiye için uluslararası konferanslar, paktlar, karşılıklı ziyaretler ve ticari anlaşmalarla geçen 1933 yılının Türk dış politikası açısından aktif bir yıl olduğu belirtilmektedir. ${ }^{4}$

1930 sonrasında Türkiye için önemli olan konulardan birisi de Lozan Boğazlar Sözleşmesine göre silahtan arındırılmış olan bölgelerin yeniden silahlandırılması olmuştur. Türkiye, 1933 yılından itibaren Lozan'da boğazlarla ilgili alınan kararların yeni bir sözleşme ile günün koşullarına uyarlanması düşüncesiyle, boğazların statüsünün yeniden gözden geçirilmesini arzu etmekteydi. Türkiye, İngiltere’yi bu konuda ikna edene kadar, İngiltere'yle arasında birtakım sorunların yaşandığı raporda belirtilmektedir, İngilizler Türkiye'nin 1933 yılında Cenevre'de düzenlenen Silahsızlanma Konferansı'nda İngiltere'nin karşı gücünü küçümseyici bir tavır takındığını ve bu doğrultuda silahtan arındırılmış sınır bölgelerini yeniden silahlandırmayı teklif ettiğini belirtmektedirler. Ancak Türkiye'nin bu teklifinin konferansta İngiltere tarafından kabul görmemesinin, Sovyetlere yakın bir politika izlemesine sebep olduğu da vurgulanmaktadır. ${ }^{5}$ Türkiye'nin teklifinin İngiltere tarafından kabul görmemesinin gerekçesi aslında Almanya'nın böyle bir durumu Ren bölgesini yeniden silahlandırmak için bir fırsat olarak kullanabileceği ihtimalinden kaynaklanmıştır. ${ }^{6}$ İngiltere'nin, verdiği kararın Türkiye'yi Sovyet Rusya ile yakınlaştırdığını düşünmesi ise aslında Türkiye'nin dış politikasında, Batı'ya karşı Sovyet Rusya ile iyi ilişkiler sürdürerek uyguladığı denge politikasından kaynaklanmıştır.

1933 yılı içerisinde Türkiye diğer ülkelerle olan bağlarını geliştirmek adına karşılıklı bir takım ziyaretler gerçekleştirmiştir. Bu çerçevede, Yugoslavya Kralı ve Kraliçesi, Yunan

\footnotetext{
4 PRO, FO, 371/17959, E 596/596/44, s.3

5 PRO, FO, 371/17959, E 596/596/44, s. 3

6 Figen Atabey, “Türk-İngiliz Siyasi İlişkileri (1936-1939)", History Studies International Journal Of History, Mart 2015, s. 28
} 
ve Macar Başbakanı, Romanya Dışişleri Bakanı’nın yanı sıra başkanlığını Savaș ve Donanma Komiseri'nin yaptığı güçlü bir Sovyet delegasyonu da Türkiye'yi ziyaret etmiştir. Sovyet delegasyonu Türk ordusu ile birlikte Ankara, İzmir ve Çanakkale'de yakın temaslarda bulunmuş ve bu ziyaret vesilesi ile Sovyetler Türkiye'ye dört uçak hediye etmiştir. Sovyetlerin Türkiye'ye vermiş olduğu bu uçaklar, Silahsızlanma Konferansı sonrasında Sovyetler ile Türkiye'nin yakınlaşmasını göstermesi açısından önemli bir gelişme olarak görülmüştür. Sovyetler yapmış olduğu bu hamleyle, boğazlar konusunda İngiltere ile sıkıntılı bir süreç yaşayan Türkiye'yi kendi tarafına daha yakın tutmak istemiştir. Yıl içersisinde Türkiye Cumhuriyeti Dışişleri Bakanı Tevfik Rüştü Aras ise Roma ve Paris'i ziyaret etmiştir. Dünya Ekonomi Konferansına katılmak üzere Londra'ya giden Türk Dışişleri Bakanı dönüşte Roma ve Paris'te kısa bir süre kalmış, daha sonra Atina ve Belgrad'a uğramış, Ekim ayı içerisinde de İsmet Paşa ile birlikte Sofya'ya geçmiştir.7

Türkiye'nin gerçekleştirmiş olduğu bu ziyaretlerin temel amacı Balkan komşuları ile ortak bir antlaşma imzalamaktır. Türkiye, Balkan komşuları ve Sovyet Rusya ile paktlar imzalayarak gerçekleștirdiği girişimlerde başarı sağlamıştır. Yunanistan ile 14 Eylül'de Samimi Antlaşma Paktı, 17 Ekim Romanya ve 27 Kasım Yugoslavya ile Dostluk, Saldırmazlık, Hakem ve Uzlașma Antlaşmaları imzalamıștır. ${ }^{8}$ Türkiye bu paktlar ile batı sınırlarını güvende tutmak isterken doğu sınırlarını da güvence altına alabilmek adına girişimlerde bulunmuştur. Bu doğrultuda, Türkiye'nin Londra Büyükelçisi 1933 yılının sonuna doğru İngiliz Dışişleri Bakanı ile bir görüşme yapmıștır. Büyükelçi bu görüşmede İngiliz Dışişleri Bakanına, Türkiye'nin amacının Ortadoğu bölgesinde de güvenliği sağlamak olduğunu belirterek İngiltere, Türkiye, İran, Irak, Sovyet Rusya ve Afganistan arasında bir saldırmazlık paktı imzalanmasını teklif etmiştir. ${ }^{9}$ Ancak böyle bir paktın 1937 yılında İngiltere ve Sovyetler Birliği katılımı olmadan gerçekleşmiş olması dolayısıyla bu teklifin İngiltere tarafından olumlu karşılanmadığı anlaşılmaktadır.

Türkiye, 16 Mart 1921 tarihinde Dostluk Antlaşması imzaladığı Sovyet Rusya'ya uyguladığı geleneksel dış politikası sebebiyle ayrı bir önem vermekteydi. ${ }^{10}$ Rapor Türkiye'nin daha önce yaşamış olduğu deneyimler dolayısıyla Sovyet Rusya ile olan bağları koparma niyetinde olmadığını belirtmektedir. Çünkü Türkiye, Sovyetler Birliğini Avrupa ülkelerine karşı bir denge unsuru olarak görmekteydi. Raporlarda da bu noktaya vurgu yapılırken Sovyetler Birliğinin, Türkiye için geçmiş deneyimleri dolayısıyla dış politikada ayrı bir yerinin olduğu ve Türkiye için Sovyetler Birliğinin yanı sıra Yunanistan'ında dostluk açısından ayrı bir yere sahip olduğu noktası da vurgulanmaktadır. ${ }^{11}$ Atatürk'ün 1933 yılında ABD'de iktidara gelen Franklin Delanoe Roosvelt'e yakın olması ve yazışmasının ${ }^{12}$ yanı sıra ABD’nin Türkiye'ye demiryolu, madenler ve havacılık sahasında uzmanlar sağlaması dolayısıyla bu ülkenin Türkiye için ayrı bir yere sahip olduğu da raporlarda belirtilmektedir. Raporda, 1930 yılından

7 PRO, FO, 371/17959, E 596/596/44, s.3

8 Atilla Sandıklı, Atatürk'ün Dış Politika Stratejisi: Hedefler ve Prensipler, Bilgesam Yayınları, İstanbul 2014, s. 85-86

9 PRO, FO, 371/17959, E 596/596/44, s. 3

10 Aleksandr Kolesnikov, Atatürk Dönemi Türk-Rus İlişkileri, Atatürk Araştırma Merkezi, Ankara 2010, s. 28

11 PRO, FO, 371/17959, E 596/596/44, s. 4

12 Füsun Türkmen, Kırllgan İttifaktan "Model Ortaklığa” Türkiye ABD İlişkileri, Timaş Yayınları, İstanbul 2012, s. 45 
sonra ilişkilerin düzelmeye başladığı İngiltere ile ise bazen sıcak bazen soğuk rüzgârlar esmekte olduğu ve Fransa ile olan ilişkilerin ise iyi düzeyde ilerleme olduğu bildirilmektedir. ${ }^{13}$ Genç Türkiye Cumhuriyeti ülke olarak ilerlemesine katkı sağlamak ve güçlü bir konuma sahip olabilmek adına dış politikasını da iyi ilişkiler geliştirerek sürdürmek istemiştir.

Raporda, genel olarak, küçük bir grubun elindeki güç yoğunlaşması ve kamuoyu yokluğu nedeniyle, Türkiye'nin yabancı ülkelere karşı tutumunda geçici şiddet dalgalanmaları olduğu belirtilmektedir. Bu durumun ise, aşırı ulusal bir zümrenin, Türkiye'nin şahsına yurtdışında gösterdiği hassasiyetle kendini açığa vurduğu belirtilirken, Türkiye'nin, kendine danışmadan doğrudan kaderini yönlendirme üzerine yapılan görüşme ve anlaşmalardan hoşlanmadığı vurgulanmaktadır. Yabancı bir gazetenin, Türkiye hakkında yayınladığı bir yazıda, Türkiye'deki bu küçük grubun tutumunun, Türkiye'nin yabancı ülkelere karşı bazen sıcak bazen soğuk tavır takınmasına sebep olduğunu yazmıştır. ${ }^{14}$ Türkiye'nin isteği kendini ilgilendiren konularda karar verilirken kendisinin de bu sürece dâhil edilmesidir.

Türkiye, 1932 yılında Milletler Cemiyeti'ne dâhil olması sonrasında, yapılan bütün toplantılara katılmış bu kurum da Türkiye'nin dış politika oluşumunda önemli bir yer tutmuștur. ${ }^{15}$ Rapora göre Türkiye'nin 1932 yılının yazında Milletler Cemiyeti'ne girdikten sonra kendi reklamını yapması ve ulusal yönde hareket etmesi, bir süre sonra cemiyetin programını sorgulamaya başlamasına sebep olmuştur. Türkiye'nin bu tavrı ile ilgili olarak Mc Donald uçuş planlarına yer verilmektedir. Tevfik Rüştü Bey Silahsızlanma Konferansına katılmış ve Türkiye'nin de içerisinde bulunduğu Mc Donald Uçuş planlarından dolayı Majesteleri Hükümetine karşı bir ön yargı gösterdikten sonra bu durumu avantajı doğrultusunda kullanabilmek için silahsız sınır bölgelerinin yeniden silahlandırılması adına bir teklifte bulunmuştur. Ayrıca Türkiye'nin ara ara cemiyete karşı eleştirilerde bulunulduğu ifade edilirken Tevfik Rüştü Aras'ın tutumuna vurgu yapılmıştır. Bakan, 1933 Aralık ayında Milletler Cemiyeti'ne karşı kibirli bir tavır takınmış ve Ankara'da önde gelen yabancı diplomatlara Cenevre'yi kınamış, cemiyetin merkezinin de Viyana olması gerektiğini belirtmiştir. Türkiye'nin bu tavrı aslında cemiyetin bu zamana kadar kendisi hakkında almış olduğu kararlardan kaynaklandığı raporlarda belirtilmektedir. Türkiye'nin kendisine zarar vermediği müddetçe cemiyete herhangi bir itirazı yoktu. Musul konusunda cemiyetin vermiş olduğu karar Türkiye'nin bu düșüncelerinin temel noktalarından biriydi. Tevfik Rüștü Aras Cemiyetin Türk-İngiliz iliş̧kilerinin iyi yönde gelişmesini engellediği noktasında da eleştiriler yapmıştır. Birkaç gün sonra Majesteleri'nin maslahatgüzarı ile yaptığı konuşmasında Cemiyet'in bugünkü ve gelecekteki programına da orta düzeyde eleştiriler getirmiştir. Tevfik Rüştü Aras Maslahatgüzara, Almanya'nın Milletler Cemiyeti'nden ayrılmasının Macaristan'ı da cemiyeti terk etme konusunda cesaretlendirebileceğinden korktuğundan dolayı, Ekim ayında Macar Başbakanı ve Dışişleri Bakanı'nın Ankara ziyaretlerinde Almanya'nın yanlış yaptığını ve Macar ziyaretçilere böyle bir adım atmamaları konusunda danışmanlık yaptığını söylemiştir. ${ }^{16}$ Tevfik Rüştü Aras'ın bu girişimi Türkiye'nin Milletler Cemiyeti bütünlüğüne ve uluslararası barışa önem verdiğini göstermektedir çünkü Almanya Milletler Cemiyeti ve Silahsızlanma

\footnotetext{
13 PRO, FO, 371/17959, E 596/596/44, s. 4

14 PRO, FO, 371/17959, E 596/596/44, s. 4

15 Şayan Ulusan, “Türkiye'nin Milletler Cemiyeti'ne (Cemiyet-i Akvam) Girişi Öncesi ve Sonrası”, ÇTTAD,

VII/16-17, 2008 Bahar-Güz, s. 247

16 PRO, FO, 371/17959, E 596/596/44, s.4
} 
Konferansı'nı terk etmesi sonrasında silahlanmaya başlamış ve barıșı tehdit eder duruma gelmiştir. Tevfik Rüştü Aras, Birinci Dünya Savașı sonrasında önemli gelişmelerden biri olan silahsızlanma girişimlerinin galip devletlerin inatçı bir siyaset takip etmelerinden dolayı iflas ettiğini ve aslında İkinci Dünya Savaşı'nın, Almanya'nın Silahsızlanma Konferansı'ndan ayrıldığı dakikada başladığını belirtmektedir. ${ }^{17}$

Türkiye Cumhuriyeti uyguladığı dış politikasıyla uluslararası arenada kendisini önemli bir konuma taşımaya başlamıştır. Bu noktada 1933 ve 1934 yılında bulunduğu girişimler ile uluslararası alanda diğer güçlü devletler ile eşitlik isteyerek, verilen kararlarda yer almak istemiş ve dışarıda bırakıldığı zamanda tepkisini ortaya koymuştur. Türkiye, ortaya koyduğu politikası neticesinde 1934 yılında Milletler Cemiyeti'nde daha önemli bir üye haline gelmiştir. 1934 yılında İran-Afgan sınır problemini çözmek adına bölgeye bu devletlerce davet edilen Türkiye, burada uluslararası problemlerin çözümünde yer almış ve bölgede önemli bir güç haline geldiğini de göstermiștir. ${ }^{18}$

\section{Balkan Paktı Sonrası Türk Dış Politikası}

Türkiye’nin 1933 yılında Balkan ülkeleri ile ilişkilerini güçlendirmek adına ikili antlaşmalar yapması, 1934 yılında Balkan Paktı'nın imzalanmasını sağlamıştır. Türkiye, tarihi bağları bulunan Balkan ülkeleri ile Balkan Paktı'nın imzalanmasında göstermiş olduğu gayret ile bölgede liderlik yapabilecek bir ülke olduğunu göstermiştir. Raporda, Türkiye'nin 1934 Şubat'ında imzaladığı Balkan Paktı ile uluslararası alanda yeni bir güç ve ağırlığı olan bir oluşumun parçası haline geldiği belirtilmektedir. Yine bu süreçte Türkiye, Sovyet Rusya ile olan ilişkilerini de devam ettirmiş ve Kayseri ile Ereğli'de maden aramasında Rus uzmanlar yer almıştır. ${ }^{19}$ Türkiye, batı sınırlarında Balkan Paktı ile sağlamış olduğu güvenliği, doğu sınırlarında da sağlayabilmek adına İngiltere'ye 1933 yılında Türkiye, İngiltere, Irak, İran ve Sovyet Rusya'nın da dâhil edildiği bir güvenlik Paktı imzalamayı teklif etmişti. Tevfik Rüştü Aras 1934 yılının Şubat ayında İngiltere'nin Ankara Büyükelçisi ile bir araya gelerek Ortadoğu Paktı konusunu tekrar gündeme getirmiş ancak Büyükelçi bu teklife pek sıcak bakmamış fakat yinede konuyu düșüneceklerini bildirmiștir. Ancak İngiltere'nin Ortadoğu Paktı ile ilgili olarak ortaya koyduğu tavırda pek bir değişiklik olmamış ve Mayıs ayında Türkiye'nin bu teklifine olumsuz yanıt vermiştir. ${ }^{20}$

1934 yılında Avrupa ülkeleri ile olan münasebetlere bakıldığında ise Türk-Fransız ilişkilerinde ilerleme kaydederken, Mussolini'nin Asya'da almış olduğu genişleme kararından dolayı İtalya ile aralarında ise kırılganlık meydana gelmiştir. İngiltere'yle olan münasebetler ise İngiliz Büyükelçisi ve Türkiye Cumhuriyeti Cumhurbaşkanı’nın iyi düzeyde olan iletişimleri dolayısıyla olumlu yönde ilerlerken, Temmuz ayında Dipburnu'nda İngiliz askerlerinin vurulması dolayısıyla ilişkiler sekteye uğramıştır. Avrupa noktasında bir diğer sıkıntı ise Balkanlarda oluşabilecek bir boşluğa sebebiyet verebilmesi dolayısıyla Bulgaristan'ın Balkan Paktı'na dâhil edilememesi olmuştur. İsveç Prens ve Prensesi'nin Türkiye ziyaretleri ise olumlu gelişmeler arasında gösterilebilir. Bu ziyaretle aralarında tarihi bir bağ olan İsveç ile

\footnotetext{
17 Aras, a.g.e, s. 86

18 PRO, FO, 371/19037, E 854/854/44, s. 3

19 PRO, FO, 371/19037, E 854/854/44, s. 3

20 PRO, FO, 371/19037, E 854/854/44, s. 4
} 
Türkiye'nin ilişkilerinde iyiye doğru bir ilerleme gerçekleşmiştir. ${ }^{21}$

Türkiye etkin olmaya çalıştığı bölgelerde dengeleri gözetir bir politika izlemiştir. Türkiye’nin dengeleri koruma politikası Orta Asya bölgesinde de kendisini göstermiştir. Türkiye, Sovyet Rusya ile olan dostane münasebetlerinden dolayı Japonya ile olan ticari ilişkilerinde gerileme yaşamıştır. ${ }^{22}$ Türkiye'nin Japonya'ya karşı bu tutumu Japonya İle Sovyet Rusya arasında gerçekleşme ihtimali olan savaş durumundan kaynaklanmıştır. Praxda'nın Paris muhabirinin Mayıs ayında Moskova'ya çektiği telgrafta, İstanbul'dan aldığı bilgilere göre, Japonya'nın Türkiye'ye gerçekleştirdiği deniz ziyaretinin, Japonya ve SSCB arasında bir savaş çıkması halinde Türkiye'nin tavrını öğrenme amaçlı olduğu belirtilmişti. Japonya, Bu ziyaret sırasında Japon Koramiral aracılığıyla Türkiye’yi, Sovyet Rusya'ya karşı AlmanJapon-Polonya ittifakına katılmaya ikna etmeye çalışmış ve savaş durumunda üç ülke, Sovyet Rusya'nın Kafkasya illeri de dâhil olmak üzere Türkiye'ye bölgesel tazminat ödemelerini vaat etmişti. Ayrıca Türkiye'nin bu ittifaka katılması durumunda Japonya Türkiye'ye bir dizi savaş deniz birlikleri vermeye hazır olduğunu bildirmiştir. ${ }^{23}$ Türkiye yine başta Doğu Türkistan'ın kurulması noktasında olumlu bir eğilime sahipken Sovyet dostluğu nedeni ile bu konuyu askıya almıştır. Daha önce sınır konusu ile sağlam bir iletişim kurmuş olduğu İran ve Afganistan'la samimi bir şekilde ilişkilerine devam etmiştir. ${ }^{24}$

Almanya ve İtalya'nın saldırgan tutumunun daha net bir biçimde ortaya çıkmış olmasına rağmen, silahtan ve askerden arındırılmış olan sınır bölgelerinin durumunda İngiltere ve diğer devletlerin Türkiye'ye destek vermemesi dolayısıyla, Türkiye'nin bu konudaki rahatsızlığı devam etmekteydi. Türkiye, Almanya ve İtalya'nın tutumuyla şartların değiștiğini ve Lozan'da boğazlar ve sınır bölgeleri ile ilgili alınan kararlarda revizyona gidilmesi gerektiğini düşündügünden dolayı, bu bölgelerin silahlandırılması konusunu daha önce Londra'da yapılan Silahsızlanma Konferansı'nda dile getirmiş ancak bu teklifi İngiltere tarafından kabul görmemişti. Türkiye, Balkanlar'daki Yugoslavya-Bulgaristan yakınlaşması ve Mussolini'nin Asya ve Afrika'daki emellerini açığa vuran konuşması sonrasında 1934 yılının bahar aylarında Milletler Cemiyeti Konseyinde bu konudaki fikirlerini tekrar gündeme taşıdı. Ancak İngiltere'nin konuyla ilgili olarak görüşlerinde herhangi bir değişiklik olmadı. Türkiye boğazlar konusunda İngiltere'nin desteğini sağlamak istediğinden dolayı meselenin görüşülmesini daha uygun bir zamana bıraktı. ${ }^{25}$

Türkiye, uluslararası meselelerde daha etkili olabilmek için 1934 yılında Milletler Cemiyeti'nde sağlam bir koltuğa sahip olmak için girişimlerine devam etmiştir. Daha önceleri cemiyete karşı ciddi eleştirilerden bulunan Tevfik Rüşü Aras, 1934 yılında daha ılımlı bir tavır sergilemeye başlamıştır. Cemiyette ülkesi için bir koltuk alabilme isteğinde olan Dışişleri Bakanı Aras, Nisan 1934'te İngiliz Büyükelçi Sir Percy Loraine ile bu konu hakkında bir görüşme yapmıştır. Bu görüşmede Aras, Almanya'nın cemiyetten ayrılmak ile ne kadar yanlış bir karar verdiği üzerinde durmuştur. Türkiye, Londra Büyükelçisi vasıtasıyla İngiltere'de de

21 PRO, FO, 371/19037, E 854/854/44, s. 3

22 PRO, FO, 371/19037, E 854/854/44, s. 4

23 PRO, FO, 371/19037, E 854/854/44, s. 21

24 PRO, FO, 371/19037, E 854/854/44, s. 4, Mehmet Gönlübol-Cem Sar, Atatürk ve Türkiye’nin Dış Politikası (1919-1938), Atatürk Araştırma Merkezi, 2013 Ankara, s. 140

25 PRO, FO, 371/19037, E 854/854/44, s. 4 
konuyla ilgili girişimlerde bulunmuştur. Türk Büyükelçi, İngiliz Dışişleri Bakanı ile görüşerek Milletler Cemiyeti Konseyi'nde Çin'den boşalan koltuğa kendilerin seçilmesi gerektiğini ifade ederken bu konuda endişeli olduklarını da bildirmiştir. Büyükelçi Fethi Bey bu görüşmede gayet hoş bir biçimde karşılanmış ancak isteği ile ilgili olarak net bir yanıt alamamıştır. Fethi Bey, kendisine gösterilen hoș tavırdan dolayı memnuniyetini bildirerek, İngiltere'nin, Türkiye'nin konsey adaylığını destekleyeceğini umduğunu belirtmiş ve Türkiye için konseyde yer almanın manevi önemine vurgu yapmıștır. ${ }^{26}$

\section{Milletler Cemiyeti Konseyi’ne Üyelik ve Türk Dıș Politikası}

Türkiye'nin Milletler Cemiyeti Konseyi'ne üye olabilmek adına yapmış olduğu girișimler netice vermiş ve 17 Eylül 1934'te kendisine konseyde yer bulmuştur. ${ }^{27}$ Raporda, Türkiye'nin konseye üye olarak seçilmesinin Türk basının da geniş yer bulduğu ve bunun politik bir zafer olarak algılandığı ifade edilmiştir. Tevfik Rüștü Aras 1933 yılında, cemiyeti "yası tutulmayan ölüm" olarak nitelerken, Türkiye'nin üyeliği sonrasında ise cemiyeti "bütün insanlığın merkezi” olarak tanımlamıștır. Raporda, Türkiye'nin bu tutumu eleştirilmiş ve İngiliz büyükelçi cemiyetin Türkiye'nin amaçları için değil daha geniş kapsamlı amaçlar doğrultusunda kurulduğunu ifade etmiștir. Ayrıca Türk basınında, Türkiye'nin yerini borçlu olduğu İngiltere ve diğer büyük güçlere yeterince yer verilmediği belirtilmiştir. Tevfik Rüștü Aras İngiliz büyükelçi ile yaptığı görüşmede desteklerinden dolayı teşekkürlerini bildirirken, konseyde İngiltere ile birlikte hareket edeceklerini belirtmiştir. Büyükelçi, hükümet boyutunda Türkiye'nin takındığı tavırdan memnun olduklarını ve bunun da ileride oluşacak Türk-İngiliz işbirliği adına sağlam bir zemin oluşturduğunun üzerinde durmuştur. Tevfik Rüştü Aras senenin sonunda Cenevre'de yapılacak olan cemiyetin konsey toplantısına katılmak üzere yola çıktığında kazanılan zaferden dolayı oldukça mutlu görünmekteydi. ${ }^{28}$ Türkiye daha önceleri cemiyetle ilgili olarak ciddi eleştirilerde bulunurken, konseye üç yıllığına üye olarak seçildikten sonra cemiyete karşı olan bakışını değiştirmiştir. Türkiye'nin bu tutumu cemiyetle daha önce yaşamış olduğu sıkıntılar dolayısıyla haklı olarak görülebilir ancak bu davranışı ile eleştiri almıştır. Ayrıca üye seçilmeden önceki dönemlerde önemli konumuna rağmen, kendisinin uluslararası konularda alınan kararların dışında bırakılmasından rahatsız olurken bu sıkıntıyı konsey üyesi olmakla aştığından dolayı cemiyete yaklaşımında da değişiklik göstermeye başlamıştır. Türkiye yine bu noktada İngiltere ile sıkı bir iletişim içerisinde politikasını geliştirmiştir.

İtalya'nın Arnavutluk işgali ve Ege'deki adaları silahlandırmaya başlaması Balkanlar ve Akdeniz'de ki güç dengesini etkilemiş ve Ankara, İtalya'yı ciddi bir tehdit olarak görmeye başlamıştır. Bu tehdit diğer ülkeler tarafından da algılanmaya başlayınca Türkiye bu süreci boğazların statüsünün değiştirilmesi konusunda kullanmak adına bir fırsatolarakgörmüştür. ${ }^{29}$ Dolayısıyla bu isteğini gerçekleştirebilmek adına Türkiye 1935 yılında dış politikada daha etkin olmaya çalışmıştır. Türkiye dünya konjonktüründe meydana gelen değişiklikler dolayısıyla boğazların statüsünde de revizyona gidilmesi adına girişimlerini sıkılaştırmıştır. Boğazlardaki değişiklik talebi noktasında Sovyetlerin de desteğini alan Türkiye konuyu

26 PRO, FO, 371/19037, E 854/854/44, s. 5

27 Şayan Ulusan, a.g.m, s.248

28 PRO, FO, 371/19037, E 854/854/44, s. 5

29 Ali Balcı, Türkiye Dış Politikası İlkeler, Aktörler, Uygulamalar, Etkileşim Yayınları, İstanbul 2013, s.42 
gündemde tutmak istemiştir.

İtalya'nın iki savaş gemisinin inşasına başlaması dolayısıyla Türkiye ve Yunanistan olası bir İtalyan saldırısına karşı donanma güçlerini ikiye katlama kararı almışlardır. Bu konuyla ilgili olarak Türk Dıșişleri Bakanı Tevfik Rüştü Aras ile İngiliz büyükelçi sık sık görüşmelerde bulunmuşlardır. Türkiye, doğu Akdeniz'de bozulan denge karşısında savunma güçlerini artırmaya ve gemi inşasının İngiliz tersanelerinde yapılmasını sağlamaya çalışmıştır. Yapılan tekliflerin İngiliz hükümeti tarafından kabul görmemesi durumunda İngiliz büyükelçi yeni teklifleri götürerek Türkiye’ye yardımcı olacağını bildirmiștir. ${ }^{30}$

Raporda, büyükelçi Türkiye'nin boğazların statüsünün tekrar ele alınma konusunun unutulmasından çekindiğini belirtmiştir. Türkiye konuyu gündemde tutabilmek adına isteklerini açık bir şekilde dile getirmekten çekinmemiştir. Mustafa Kemal Atatürk Mayıs 1935'te bu konuda Sovyetlerinde kendilerini açık bir şekilde desteklediğini ifade etmiş ancak Türkiye asıl destek beklediği ülke olan İngiltere'den arzuladığı desteği görememiştir. İtalya'nın tutumunun Milletler Cemiyet'ini büyük oranda meşgul etmesinden dolayı Türkiye boğazların statüsünde değișiklik isteğinin unutulmamasını sağlamak adına uygun bir zaman kollamıştır. ${ }^{31}$

1934 sonrası İran'ın Kürt isyanlarına karşı tedbirler almasıyla ${ }^{32}$ birlikte bu ülke ile ilişkilerini düzeltmesinin yanı sıra Sovyetler ve Irak'la da iyi münasebetler içerisinde olması, Türkiye'ye artan İtalya tehlikesi karşısında askeri açıdan daha rahat hareket imkânı sağlamış ve doğu sınırında yer alan askeri birliklerinin birçoğunu batıya kaydırma fırsatı vermiştir. Türkiye'nin batı sınırlarının güvenliğini sağlamak adına Trakya bölgesine göndermiş olduğu askerlerin yanı sıra boğazları da silahlandırma isteği Bulgaristan'ı endișelendirmiştir. Türkiye ise bu politikasını, gerektiğinde Balkan Paktı ile birlikte olduğu ülkeleri korumak olarak tanımlarken, Bulgaristan'ın da pakta üye olmamasından dolayı dikkat edilmesi gereken bir ülke olduğu belirtmiştir. Ayrıca Türkiye, Yunanistan'daki ayaklanmanın Trakya'daki asker sayısının arttırılmasında etkili olduğunu ve Trakya'yı yıllarca çektiği acılardan kurtarma anı geldiğinde bölgeyi tekrar nüfuslandırarak koruyacaklarını vurgulamıştır. ${ }^{33}$

Türkiye batı ile olan ilişkilerinin yanı sıra doğu ülkeleri ile olan ilişkilerine de önem vermiştir. Türkiye'nin Sovyetlerle olan dostluğu sıkı bir şekilde devam ederken Müslüman ülkeler olan İran, Irak ve Afganistan ile iyi ilişkilerini devam ettirmiş ancak Suudi Arabistan ve Mısır'a biraz daha mesafeli olmuştur. Türkiye 1935 yılında da Ortadoğu'da güvenliği sağlayabilmek adına İran ve Irak'a saldırmazlık anlaşması önerisinde bulunmuştur. Doğu ülkeleri ile olan ilişkilerdeki uyum batı ülkelerinde de aynı şekilde kendisini göstermiştir. 1935 yılında İtalya ile Milletler Cemiyeti arasındaki gerginlik gittikçe büyürken, Türkiye Milletler Cemiyeti'nin davasına kenetlendiğini bildirmiş ve İtalya'yı kınamıștır. ${ }^{34}$

1932 yılında cemiyete dâhil olan Türkiye ilk dönemlerde, cemiyetle geçmişte yaşamış

30 PRO, FO, 371/19037, E 854/854/44, s. 8

31 PRO, FO, 371/20091, E 933/933/44, s. 3

32 Yuluğ Tekin Kurat, "Elli Yıllık Cumhuriyetin Dış Politikası (1923-1973)”, Belleten, Sy.154, 1975, s.268

33 PRO, FO, 371/20091, E 933/933/44, s. 3-4

34 PRO, FO, 371/20091, E 933/933/44, s. 4 
olduğu sıkıntılar nedeniyle kuruluşa karşı soğuk bir duruş sergilerken, 1935 yılında gittikçe büyüyen İtalyan krizinin yanı sıra İngiltere ile arasının düzelmeye başlaması, Türkiye’yi cemiyete en bağlı isimlerden biri haline getirmiştir. Türkiye, cemiyet içerisindeki çalışmalarda aktif bir biçimde yer alırken, Tevfik Rüştü Aras Cemiyet Konseyi'nin başkanı olarak, 1935 yılının başından itibaren bir seri önemli toplantıya başkanlık yapmıștır. Türkiye, Ekim ayı içerisinde Etiyopya sorununun çözümü hakkında teklif sunan ve İtalya tarafından reddedilen beşler komitesinin ve İtalya'ya ekonomik yaptırımlar düzenleyen on sekizler komitesinin üyeliğini yapmıştır. ${ }^{35}$ Türkiye'nin İtalya'ya karşı yaptırımlarda yer alması dolayısıyla 11 Kasımda İtalya, Türkiye'ye protesto içerikli bir nota göndermiştir. Türkiye ise bu kararın Milletler Cemiyeti tarafından alındığını belirtmiştir. ${ }^{36}$ Türkiye için İtalya'ya karşı alınan tedbirler elbette önemliydi, İtalya'nın kendisini tehdit etmesini engellemek isterken cemiyete bağlı bir politika izlemesi işini kolaylatırmış ve tek başına İtalya'yı karşısına almamıștır.

Türkiye'nin Milletler Cemiyeti'ne olan yaklaşımı İngiltere ile daha da yakınlaşmasını sağlamıştır. Haziran 1935'te imzalanan “Ticaret ve Ödemelerle” ilgili anlaşmanın yanı sıra Suriye ve Ürdün'de bulunan siyasi göçmenlerin Atatürk'e düzenlemeyi planladıkları suikastın İngiltere tarafından Türkiye'ye haber verilmesi iki ülke arasında ilişkilerin gözle görülür bir șekilde geliștiğinin göstergesi olmuștur. Türkiye'nin, Akdeniz'deki İngiliz donanmasına İtalya'nın saldırması durumunda bu saldırıyı bertaraf etmek adına İngiltere ile işbirliği içerisinde olacağının garantisini vermesi dostluk seviyesini artıran bir başka etken olmuştur. ${ }^{37}$

Aras, İtalyan krizinin çözüme kavuşturulması adına Beşler olarak İtalya'ya yapılan teklifin cevabının cemiyet defterdarlığı tarafından cemiyete haber verilmeden açıklanması karşısında şok oldukları belirtirken, İngiliz Büyükelçi Sir Percy Loraine'e Türkiye'nin anlaşma gereği yükümlülüklerini yerine getireceğine dair teminat vermiştir. Aras krizin erken dönemlerinde, konseyin bir üyesi olarak anlaşmanın savunulması adına İngiltere'yi sonuna kadar takip edeceklerini ve gerekli görüldüğü takdirde Almanya ile çok büyük önemi olan ekonomik ilişkilerini dahi kesebileceklerini ifade etmişti. Ayrıca Aras konseyde olmaya devam ettikleri müddetçe tavırlarında herhangi bir değişiklik olmayacağını belirtmiştir. Bakan Türk-Fransız ilișkilerini Cemiyet anlaşmasının yattığı bir yastığa benzeterek bu anlaşmanın sarsılmaz olacağı vurgulamıştır. ${ }^{38}$

Türk Dışişleri Bakanı Aras başka bir açıklamasında Türkiye’nin anlaşma çerçevesinde görevini yerine getirirken hiçbir tereddütte bulunmayacağını buna bağlantılı olarak herhangi bir sorun karşısında Türk hükümetinin davranışlarında herhangi bir değişiklik meydana gelmeyeceğini belirtmiştir. Bakan ayrıca Atatürk'ün üç konuda hükümete öğütlerde bulunduğunu söyleyerek bunlardan birincisinin; kolektif güvenlik ve rejimde barışı korumak, ikincisinin cemiyetin anlaşmasının tam korunması ve üçüncüsünün ise ulusal savunmanın askeri güç ile daha da güçlendirmek şeklinde olduğunu açıklamıştır. Sene sonunda Bakan, Cumhurbaşkanının davranışlarının her zaman cemiyetin yanında olacak şekilde, barış ve savunma üzerine geliştiğinin vurgusunu yapmıştır. Aras, Cumhurbaşkanından cemiyet ideolojisini savunma adına uzunca bir direktif aldığını belirterek bunların; bütün enerjinin

35 PRO, FO, 371/20091, E 933/933/44, s. 4-5

36 Arzu Al, Türk Dış Politikası 1918-1980, Kaknüs Yayınları, 2014 İstanbul, s. 83

37 PRO, FO, 371/20091, E 933/933/44, s. 4, Şayan Ulusan, a.g.m, s. 249-250

38 PRO, FO, 371/20091, E 933/933/44, s. 5 
cemiyetin küçülme yaşamaması ve İtalya-Etiyopya çatışmasında bir yenilgiye uğramaması üzerine olduğunu belirtmiștir. ${ }^{39}$

Türkiye Cumhuriyeti Başbakanı Ankara'da yapılan kongredeki konuşmasında Türkiye'nin birinci önceliğinin kendisinin barıș içerisinde yașamasını sağlayacak olan şartlara bağlı kalmak olduğunu ve geriye dönüp bakıldığında Türkiye'nin, güvenlik amacıyla yapılan anlaşmaların Milletler Cemiyeti'ne olan bağlılık çerçevesinde gerçekleștiğini belirtmiş ve bu şekilde cemiyete olan inancını ifade etmiştir. Türkiye'nin cemiyetten beklentisi kolektif barıșı sağlaması olmuş ve bu noktada Türkiye cemiyete yardımcı olabilmek adına her türlü girișimi yapan ülkelerin başında gelmiştir. ${ }^{40}$ Türkiye meydana gelen gelişmeler dolayısıyla 1935 yılından itibaren cemiyete daha yakın bir tutum sergilemiş ve her firsatta cemiyetin anlaşmasına ve cemiyete bağlılık açıklamalarında bulunmuştur. Bu, Türkiye'nin İngiltere ile olan ilişkilerine de olumlu etki yapmıştır. Türkiye, ortaya koyduğu bu politikası ile kendisini ve dünyayı ilgilendiren konuların görüşülmesinde dışarıda kalmayarak inisiyatif almayı hedeflemiştir.

Türkiye 1935 yılında ülkeyi modernize etme ve daha da güçlü bir hale getirebilme adına girişimlerine devam etmiştir. Bu konuda kaçınılmaz olarak yabancı desteğe ihtiyaç duymuştur. Türkiye'ye, Sovyetler Nazilli'deki tekstil fabrikaları ve havacılık alanında, Fransız uzmanlar finans alanında, Almanlar ise üniversiteler, tarım, şehir planlama ve savunma alanında destekte bulunmuşlardır. ${ }^{41}$

1936 yılı Türkiye için dış politikada istikrarlı ve başarılı bir yıl olarak geçmiştir. Türkiye İtalya'nın Akdeniz'de oluşturduğu tehdide karşı duruşunu bozmamış ve Milletler Cemiyeti'nin yanında olduğunu belirtmiştir. Ayrıca uzun süredir uğraştığı boğazların statüsünün değiştirilmesi konusunda da isteklerini kabul ettirmeyi başarmış ve Montrö Boğazlar Konferansının toplanmasını sağlamıştır. Türkiye ortaya koyduğu politikalarla ile anti-revizyonist bir tutum içerisinde olduğunu göstermiştir.

\section{4. İtalya'nın Genişleme Politikası İle Şekillenen Türk Dış Politikası}

1936 yılının ilk yarısında Türkiye’nin İtalya'nın Habeşistan işgaline olan yaklaşımı, İtalya'nın Ankara Büyükelçisinin Türk hükümetine memnuniyetsizliğini tehditkar bir biçimde dile getirmesine yol açmıştır. Bu durum karşısında Türk-İngiliz hükümet ve askeri yetkilileri bir araya gelerek İtalya'nın saldırgan tutumu karşısında bilgi alışverişi yaparak durum değerlendirmesinde bulunmuşlardır. Bu görüşmeler İtalya’yı memnun etmezken, 1928 yılında imzalanan Türk-İtalyan dostluk anlaşmasına münasip olamayacak bir şekilde düşmanca bir mesaj göndermesine sebep olmuştur. Türkiye bu noktada Milletler Cemiyeti'ne olan bağlılığını göstermiş ve cemiyete üye olmasından kaynaklanan gereklilikler dışında herhangi bir şey yapmadığını, İtalya'ya saldırma niyetinin olmadığını ve sadece kendisini savunma ve kolektif bir barış anlayışıyla hareket ettiğini göstermek istemiştir. Türkiye'nin takınmış olduğu bu tutum karşısında İtalya ile olan ilişkiler normal bir seviye almaya başlamıştır. ${ }^{42}$

39 PRO, FO, 371/20091, E 933/933/44, s. 5

40 PRO, FO, 371/20091, E 933/933/44, s. 5

41 PRO, FO, 371/20091, E 933/933/44, s. 4

42 PRO, FO, 371/20866, E 823/823/44, s. 3 
Raporda Türkiye'nin Sovyetlerle olan ilişkileri dış politikasının temel eksenini oluşturduğundan dolayı iyi bir şekilde devam ettiği ancak Türkiye'nin İngiltere ile olan ilişkilerindeki iyi yönde yaşanan gelişmeler Türkiye'nin diş politika ufkunda gelecekte Sovyetlerin daha az etkisi olacağı ifade edilmiștir. ${ }^{43}$ Türkiye uyguladığı politika ile karada kuvvetli Sovyetler ile denizde kuvvetli İngiltere'yi dengelemiştir. ${ }^{44}$

Türkiye'nin, İtalyan tehdidi karşısında, Milletler Cemiyeti politikalarına bağlılı̆̆ı ve barıș koruma adına geliștirdiği politikası kendisine İngiltere ile daha yakın ve dostane bir çalışma olanağı sunmuştur. İki ülke arasındaki ilişki dostane bir biçimde gelişirken bu gelişme kendisini somut bir biçimde Cumhurbaşkanı Mustafa Kemal Atatürk'ün tavırlarında, Kral George'nin ölümü ve Kral VIII. Edward'ın Ekim ayı içerisinde Çanakkale ve İstanbul'a yapmış olduğu gezilerde göstermiștir. Ayrıca Avustralya savaş gemileri Australia ve Sydny'in Nisan ayında Çanakkale ziyaretleri ile Kasım ayında Türk filosunun Malta ziyareti de başarılı ve dostluk havası içerisinde gerçekleșmiștir. ${ }^{45} 1935$ yılı itibariyle İtalya'nın saldırgan politikaları karşısında iki ülkenin yakınlaşmasının yanı sıra yapılan bu ziyaretler de İngiltere ile Türkiye arasında 1930 öncesinde yaşanan ve kötü hatıralar bırakan olayların yerini ittifak ve dostluğun almasını sağlamıştır.

Türkiye Boğazların statüsünün tekrar gözden geçirilmesi konusundaki ısrarını devam ettirmiştir. Nisan ayında bu konunun daha fazla üzerinde duran Türkiye, mevcut anlaşmanın Boğazların savunulmasını yetersiz kıldığını ve boğazların tekrar silahlandırılmasının önemli olduğunu vurgulamıştır. Türkiye, teklifi kabul edilmediği takdirde Boğazları herhangi bir düzenlemeye gerek duymaksızın silahlandırmaya dair bir plan dahi hazırlamıştır. Türk yetkililer İngiliz Büyükelçisi ile görüşerek böyle bir adım atmaktan vazgeçmiş ve ortak bir karar ile bir sonuca varmanın kendileri için daha iyi olacağını düşünmüşlerdir. Türkiye'nin boğazlar konusundaki girişimleri sonuç vermiş ve Nisan ayında gönderilen notayla Boğazların statüsünün tekrar görüşülmesine karar verilmiştir. Ancak daha önce Lozan Boğazlar görüşmesinde yer alan İtalya Montrö Boğazlar Konferansına katılmamıștır. Haziran 1936 yılında Montrö Boğazlar Sözleşmesi imzalanmıș ve Türkiye ise dıș politikada izlemiș olduğu ısrarlı ve yapıcı siyasetin sonucunu olumlu yönde almıștır. Türkiye'nin Boğazların statüsündeki değişikliği zor kullanmaktan ziyade anlaşmalı bir biçimde çözüme kavuşturması Milletler Cemiyeti'ni terk eden ülkeler dışındakileri memnun etmiştir. ${ }^{46}$ Türkiye'nin İtalya'ya karşı alınan tedbirlere katılmış olması, İtalya ile olan ticari ilişkileri açısından zararlı sonuçlar doğurmuşsa da Türkiye fedakarlığını milletlerarası barışın korunması için kurulan bir teşkilatın politikalarına bağlı kalarak göstermiştir. Bunun neticesini de Montrö Boğazlar Konferansı'nın toplanmasını sağlayarak almıștır. ${ }^{47}$

1936 yılı itibariyle dış politikasında İngiltere'ye daha yakın bir çizgide olan Türkiye'nin İngiltere ile olan ilişkileri sadece siyasi alanda değil ekonomik alanda da gelişme göstermiştir.

\footnotetext{
43 PRO, FO, 371/20866, E 823/823/44, s. 3

44 Mustafa Yılmaz, “İngiliz Büyükelçiliği Yıllık Raporlarında Türkiye (1935-1938)”, Beşinci Uluslararası Atatürk Kongresi, Atatürk Araştırma Merkezi, Cilt 1, 8-12 Aralık, 2003 s. 640

45 PRO, FO, 371/20866, E 823/823/44, s. 3

46 PRO, FO, 371/20866, E 823/823/44, s. 4

47 İsmail Soysal, “Türkiye'nin Batı İttifakına Yönelişi (1934-1937)”, Belleten, Sayı. 177, 1982, s. 116, Mehmet Gönlübol-Cem Sar, a.g.e, s. 129-130
} 
Türkiye'de kurulacak olan demir çelik fabrikalarının İngiliz firmalara verilmesi ile ilgili anlaşmalar yapılmıştır. Bu anlaşmalar arasında fabrikaları yapacak olan Brassert firması ile olan anlaşmanın yanı sıra 1936 yılı donanma anlaşması da yer almıştır. İmparatorluk kapsamında ise Türkiye ile İrlanda bağımsız devleti ile ticaret anlaşması imzalamıştır. Türkiye, Kanada ve diğer kolonilerle de ticaret anlaşması yapmak istemiș ancak bu girișiminde başarıya ulaşamamıştır. ${ }^{48}$

Türkiye dış politikasında çevresindeki ülkelerle olan iyi ilişkilerini sürdürmeyi devam ettirmiştir. İran ve Irak'ın arasındaki sınır sorunun çözümünde etkili olan Türkiye bölgede inisiyatif almaya devam etmiştir. Afgan Savaş Bakanı ve Dışişleri Bakanı Türkiye’ye ziyarette bulunmuşlardır. Yine Balkan ülkeleri ile olan ilişkilerde mükemmel bir seviyede devam etmiştir. Almanya, Türkiye'ye en çok mal satan ülke olmanın yanı sıra Türkiye'nin de en iyi müşterileri arasında yer almıştır. Almanlar bu dönemde Türkiye'de danışman ve Profesör olarak daha fazla iş bulmuşlardır. Dr. Schacht'ın Türkiye'ye bu dönemde bulunduğu ziyaret, Almanların Türkiye'ye verdiği önemi göstermektedir. Rapora göre Dr. Schacht'ın Türkiye ziyaretinin amacı, Türkiye'yi ekonomikaçıdan Almanya'ya daha fazla bağımlı bir hale getirmek, İngilizlerin ülkede kapsadığı genișliğe bakarak Alman-Türk ișbirliğini geliștirme politikaları üretmek ve Fransız-Rus kombinasyonuna karşı Türk-Sovyet ilişkilerini incelemektir. ${ }^{49}$ Ancak Dr. Schacht'ın yapmışolduğu ziyaret Almanya açısından pek başarılı olmamıştır. Türk Hükümeti 1936 yılından itibaren Almanya'nın Türkiye'deki ekonomik etkisini azaltma politikası izlemiş ve Almanya'yla ticaretin bir bölümünün serbest dövizle yapılması noktasında ısrar etmiștir. ${ }^{50}$ Fransa ile Türkiye arasındaki ilişkiler ise dostane bir biçimde ilerlemeye devam etmiştir. ${ }^{51}$

\section{Montrö Boğazlar Sözleşmesi Sonrasında Türk Dış Politikası}

1936 yılında Montrö Boğazlar Sözleşmesi'nin imzalanması ile Türkiye'nin boğazların statüsünde değişiklik talepleri yerini bulmuş ve Türkiye yürüttüğü dış politikanın karşılığını almıştı. Raporda, 1937 yılından genel olarak bahsederken, Türkiye'nin dış politikasının oturmuş olduğu eksende devam ettiğini ve yabancı ülkelerle olan dostluğunun gelişmiş ve güçlenmiş olduğunu vurgulanmıştır. Sovyetlerle olan ilişkilerde bazı yüzeysel sıkıntılar çıkmaya başlamışsa dahi geçmişten gelen dostluğun iki ülke ilişkilerini belli bir düzeyin altına indirmediği belirtilmiştir. ${ }^{52}$ Montrö sonrasında Türk ve Rus dışişleri bakanları Ekim 1936 Milletler Cemiyeti Genel Kurulu'nda bir araya geldiklerinde, Litvinov, Aras'a Türkiye-İngiltere ilişkilerinin iyileşmesinde memnun olduğunu iletirken bunun Türk-Sovyet dostluğunun yerine geçmemesini umduğunu belirtmiştir. ${ }^{53}$ Türkiye ile Sovyetler arasında yaşanan sıkıntılar Montrö Boğazlar Konferansı'ndan kaynaklanmıștır. Konferanstan istediği sonucu alamayan Sovyetler, konferans sırasında Türkiye'nin İngiltere'ye yakın bir siyaset uygulamasından da

48 PRO, FO, 371/20866, E 823/823/44, s. 3

49 PRO, FO, 371/20866, E 823/823/44, s. 4

50 Ludmila Jivkova, İngiliz-Türk İlişkileri 1933-1939, Çev: F. Muharrem-F. Erdinç, Habora Kitapevi, İstanbul 1978, s. 124

51 PRO, FO, 371/20866, E 823/823/44, s. 4

52 PRO, FO, 371/21935, E 2214/2214/44, s.3-4

53 Saime Yüceer, “Atatürk Dönemi (1919-1938) Türk-Rus İlişkilerinin Siyasi Boyutu”, Atatürk’ten Soğuk Savaş Dönemine Türk-Rus Iliş̧kileri, Atatürk Araştırma Merkezi, I. Çalıştay Bildirileri Ankara, 14-15 Mayıs, 2010, s.101 
rahatsız olmuştur. ${ }^{54}$ Jivkova, Montrö'de İngiltere'nin Türkiye'nin önerisini desteklemekle, Türkiye'yi Sovyetlerden uzaklaştırmayı amaçladığını belirtmektedir. ${ }^{55}$ Raporda ayrıca Türkiye'nin Balkan Paktı ülkeleri ile iyi ilişkiler içerisinde olduğu ve yıl içerisinde imzalanan Sadabat Paktı ile güvenlik politikasına devam ettiği belirtilmiştir. İngiltere ile olan ilişkilerde gayet iyi gitmekteydi. İngiliz Büyükelçi Sir Percy Loraine Türklerin her sevincinin, üzüntüsünün ve endişesinin ortağı olmuştur. İki ülke arasındaki ilişkiler güven ve dostluk havası içerisinde devam ederken, Türkiye'nin zor ve karışık konularda majesteleri hükümetine danışması sanal bir kural haline gelmiștir. Türk Fransız ilișkilerinde ise İskenderiye sancağı bazı sıkıntılara yol açmışsa da daha sonra bunlar aşılmıştır. ${ }^{56}$

Rapor Türkiye'yi tanımlarken, değişen dünyada, kültürün müdahil olduğu bir çağda ve yeni rejimleri kabul ettirme noktasında zor olan bir bölgede Türkiye'nin çok hızlı bir ilerleme sağladığını vurgulamıștır. İngiltere ile olan dostluğunun ve ona olan inancının bunun gerçekleşmesinde önemli bir yerinin olduğu belirtilmiştir. Bunların yanı sıra Türkiye'nin kendi çıkarları yönünde yapmış olduğu girişimlerin bunun şekillenmesinde söz sahibi olduğu üzerinde de durulmuştur. ${ }^{57}$

\section{1937 Yılı Sonrası Türk Dış Politikası}

Türkiye 1937'de Milletler Cemiyeti'ne destek vermeye devam etmiştir. 1937 raporunda Türkiye'nin Milletler Cemiyeti'ne bakışı hakkında bilgi vermek adına İsmet İnönü'nün yapmış olduğu konuşmaya yer verilmiştir. İnönü, yaptığı konuşmasında cemiyetin gücü ve zayıflığı hakkında yapılan tespitlerin fazla abartılı olduğunu vurgulamıştır. Cemiyetin büyük problemleri kolayca çözmesini beklemenin ütopya olacağını belirten İnönü, cemiyetin faydasız olduğunu söylemenin de yersiz olduğunu ifade etmiştir. İsmet İnönü cemiyetin zayıflığının bazı güçlü devletlerin oluşumun dıșında kalmasından kaynaklandığını ve o devletlerin cemiyet içerisindeki devletler ile güçlerini birleştirmeleri durumunda cemiyetin gücünün ciddi bir biçimdeartacağınıbelirtmiştir. İnönü konuşmasındaayrıca şu hususlar üzerinde de durmuştur: “Türkiye'nin isteği bu yöndedir, fakat mevcut durum da küçümsenecek vaziyette değildir. Birçok ülke kendilerinin barışa destek olduklarını belirtmektedir, ülkelerin bir araya gelerek birbirlerini anlamaları gerekmektedir. Birçok tecrübe Milletler Cemiyeti'nin problemlerin çözüldüğü çalışmaların yapıldığı ve çareler bulan bir kurum olduğunu göstermiştir. Amacı bütün dünyanın katkıda bulunmasıdır. Türk hükümeti, cemiyetin yararlı ve prensiplerine uygun politika izlediğine yürekten inanmıștır”. 25 Haziran'da Dışişleri Bakanı Aras'da İsmet İnönü ile aynı fikirde olduğunu belirtmiş ve bu açıklamalar genel olarak Türkiye'de takdir toplamıştır. ${ }^{58}$ İsmet İnönü ve dışişleri bakanı Aras'ın yapmış olduğu açıklamalar Türkiye'nin Milletler Cemiyeti'ne bağlılığını ve politikasını da cemiyetin politikasına eş değer bir şekilde geliştirdiğinin göstergesidir.

Rapordan Türkiye'nin Milletler Cemiyeti politikasının bir devlet politikası haline geldiği anlaşılmaktadır. Zira raporda, İnönü sonrasında 25 Ekim 1937 tarihinde Başbakanlığa

\footnotetext{
54 PRO, FO, 371/21935, E 2214/2214/44, s. 3-4

55 Jivkova, age, s. 95

56 PRO, FO, 371/21935, E 2214/2214/44, s. 3-4

57 PRO, FO, 371/21935, E 2214/2214/44, s. 4

58 PRO, FO, 371/21935, E 2214/2214/44, s. 5
} 
gelen Celal Bayar hükümeti kurulduğunda da Türkiye'nin Milletler Cemiyeti noktasında tavrının değişmediği belirtilmiştir. 1 Kasımda Atatürk, mecliste yapmış olduğu konuşmasında Türk hükümetinin cemiyetin geçmiş olduğu zorlu süreçte bu kurumun yanında bulunacağını ifade etmiştir. Yeni Başbakan bir hafta sonra yapmış olduğu bir konuşmasında ise cemiyetin Türk dış politikasının temel etkenlerinden birisi olduğuna vurgu yapmış ve cemiyetin zorunluluklarını yerine getirmekten ziyade kendisini zamana adapte etmesi gerektiğini ve tecrübelerinden faydalanarak çözümler bulması gerektiğini belirtmiştir. ${ }^{59}$

1937'nin son aylarında Türkiye'nin Cemiyet Konseyi'ne tekrar seçilme süresi gelmişti. Raporda bu süreç hakkında bilgi verilmiştir. Eylül'de Londra'da yapılan kurul toplantısında Türk maslahatgüzar Türkiye'nin konseye tekrar seçilmesi hususunda Majesteleri hükümetinin desteğini istemiş ve bu konuda İngiltere'den dostlarını da Türkiye'ye oy vermeleri noktasında yönlendirmesini arzu etmiştir. Bu konu hakkında düşünmeleri gerektiğini belirten İngiliz hükümeti, bu tür konularda kendilerini bağlayacak sözler vermenin ilkeleriyle uyuşmadığını da belirtmişlerdir. Yapılan seçimler sonrasında Türkiye konseye tekrar seçilmemiş ve bu durum daha sonra İngiltere tarafında bir pişmanlık oluşturmuştur. Bu pişmanlık muhtemelen İngiltere ile Türkiye'nin işbirliğine rağmen ve Türkiye'nin konsey dışında kalmasında oluşmuştur. Çünkü İngiltere için Türkiye'nin konumu yaşanan olaylar dolayısıyla daha da önemli bir hale gelmişti. Raporda bu başarısızlığın arkasındaki etkenlerden birisinin İsmet İnönü'nün emekliye sevk edilmiş olmasının olabileceği vurgulanmıştır. ${ }^{60}$ İsmet İnönü başbakanlığı döneminde Türkiye, İngiltere ile çok sıkı ilişkiler geliştirmişti. İnönü 1937 yılında İngiliz Kralı'nın taç giyme törenine katıldığında İngiliz hükümeti tarafından samimi kabul görmüştü. ${ }^{61}$

Almanya, Montrö Boğazlar Sözleşmesi imzalanmış olmasına rağmen, Londra'daki elçisi aracılığı ile bu sözleşmeden duyduğu rahatsızlı̆̆ı İngiliz hükümetine dile getirmiștir. Almanya 1937 yılının başlarında Ankara hükümetine de benzer şikâyetlerde bulunmuştu. Almanya'nın itiraz etmesinin sebebi sözleşmenin Almanya aleyhine hükümler içermesinden kaynaklanmaktaydı. Almanya, Sovyetler ile yakın ilişkisi olan Türkiye'nin izni ile Sovyet gemilerinin savaş zamanında boğazlardan geçerek saldırı yapıp geri dönme ihtimalinin olduğunu ve bundan rahatsızlı duyduklarını belirtmiștir. İngiltere ile Türkiye Almanya'nın bu şikâyetlerine karşllıklı görüşmeler neticesinde cevap vermişlerdir. ${ }^{62}$

Türkiye'nin dış politikasının temelini barış anlayışı oluşturmaktaydı. Türkiye özellikle çevresindeki devletlerle iyi ilişkiler içerisinde olma yönünde bir siyaset geliştirmiştir. Bu noktada 1934 yılında Balkan Paktı'nın oluşturulması için yoğun bir çaba sarf ederek karşılığını gören Türkiye, bu kez Doğu ülkeleriyle bir pakt oluşturmak istemiştir. Rapor, Türkiye'nin bu hususta daha önce girişimlerde bulunduğunu ve İngiltere'ye doğuda Sovyetlerinde dâhil olacağı bir pakt teklifinde bulunduğunu belirtmektedir. Ancak bu İngiltere tarafından kabul edilmeyince Türkiye'nin bu isteği kabul görmemiști. 1937 yllında Türkiye Irak, İran ve Afganistan'ın katılımıyla Sadabad Paktı'nın oluşumunda öncü bir rol oynamıştır. 8 Temmuz 1937 yılında imzalanan Sadabad Paktı'na göre taraflar birbirlerinin içişlerine karışmayacak

59 PRO, FO, 371/21935, E 2214/2214/44, s.6

60 PRO, FO, 371/21935, E 2214/2214/44, s. 6

61 Figen Atabey, a.g.m, s. 30

62 PRO, FO, 371/21935, E 2214/2214/44, s. 7-8

Journal of History and Future, August 2017, Volume 3, Issue 2 DERGi 
ve sınırlarının dokunulmazlığına uyacaklardı. Sadabad Paktı'nın imzalanmasında Türkİngiliz ilişkilerinin özellikle 1935 sonrasında gelişme göstermesi etkili olmuştur. Aslında Sadabad Paktı ile Ortadoğu'da oluşabilecek saldırılara karşı da bir önlem alınmak istenmiștir. ${ }^{63}$ İngiltere'nin bu paktı desteklemesi olası bir savaş durumunda Ortadoğu'nun güvenliğini lehine sağlayabilmek adına olmuştur.

1937 yılında gündeme gelen bir başka pakt ise Karadeniz'de oluşturulmak istenen işbirliği üzerine olmuştur. Raporda, Türk dışişleri bakanının İngiliz büyükelçiye 1937 baharında Romanya dıșişleri bakanının Ankara'da bulunduğu sırada Karadeniz'de bir pakt kurulmasını teklif ettiğini bildirdiği yer almaktadır. Bu pakt Rusya, Romanya ve Bulgaristan arasında düşünülmekteydi ancak Türkiye bu teklife pek sıcak bakamamaktaydı. Böyle bir paktın yararlı olmadığını düşünen Türkiye bu konuda İngiltere'nin de fikrini almak istemekteydi. İngiliz dışişleri bakanlığı böyle bir paktın verimli olamayacağını ve İtalya ile Almanya'nın da böylesi bir girişimi yanlıș anlayabileceklerini düşünüyordu. Ayrıca İngiltere böylesi bir paktın Sovyetler tarafından düşünüldüğünü ancak Romanya aracılı̆̆ı ile dile getirildiğini düşünmekteydi. Sovyetler kendi kontrolünde kurduracağı böyle bir pakt ile psikolojik bir üstünlük elde etme niyetindeydi. ${ }^{64}$

Raporda Fransa ile Türkiye arasında ilişkilerin İskenderun Sancağı meselesi dolayısıyla yine sıkıntılı bir döneme girdiği belirtilmekteydi. Türkiye Cumhurbaşkanı tarafından konunun "milli bir mesele" şeklinde görüldüğü ve iki ülke ilişkileri arasında mihenk taşı olduğu vurgulanmıștır. Bu konunun uzlaşmaz ve saldırgan hale gelmesinin sebebi olarak basının ve hükümetin konuyu kendi özlemlerine uygun olarak çözüme kavuşturmak istemelerinden kaynaklandığı vurgulanmıştır. Fransa ile Türkiye arasında yapılan görüşmeler sonuç vermeyince İngiltere meselenin çözümü için arabulucu olmuştur. ${ }^{65}$ Türkiye'ye saldırgan olmayan bir biçimde sorunun halledilmesi gerektiği vurgulanırken, Fransa'ya da aynı şekilde çözüm bulunması yönünde tavsiyelerde bulunulmuştur. 29 Mayıs 1937'de anlaşmaya varıldı ancak sorun 1938'de devam etti. 3 Temmuz 1938'de Sancağın idari ve siyasi statüsünde bir anlaşma yapıldı ve Sancak yapılan seçimler sonrasında 1938 yılının Eylül ayında bağımsızlığını ilan etti. ${ }^{66}$

Raporda 1937 yılı Türkiye ile İngiltere’nin ilişkilerinin iyi yönde daha hızlı geliştiği bir yıl olduğu belirtilmiştir. Türk hükümetinin yıl boyunca Türk dış politikasının neredeyse tüme cephelerinde Akdeniz, Almanya, Balkanlar, Karadeniz ve Ortadoğu'da İngilizlerin tavsiyelerini alması yönünde istekli tavırları olduğu belirtilmiştir. Raporda, Türkiye'nin Akdeniz'de İngiltere'nin onayının olmadığı hiçbir şeyi kabul etmeyeceği ve Almanya ile birlikte hareket ettiği geçen savaşta (I. Dünya Savaşı) yaptığı hatayı tekrarlamayacağı ve Türkiye'nin çıkarlarının İngiltere'yle birlikte olmaktan geçtiği yer almıştır. ${ }^{67}$ 


\section{Sonuç}

1933-1937 yılları, Türkiye'nin dış politikasında daha aktif bir rol oynamaya başladığı ve kendi güvenliğini sağlamak üzere çeşitli paktların içerisinde yer aldığı dönem olması dolayısıyla oldukça önemlidir. Bu yıllar arasında Türkiye'nin uyguladığı dış politika'nın İngiliz Büyükelçilik raporlarında ele alınışına bakıldığında, Türkiye Cumhuriyeti'nin sınır güvenliğini sağlamak ve kendisini bir güç olarak kabul ettirme yönünde bir siyaset geliştirdiği görülmektedir. Türkiye, ülke içerisindeki gelişimini büyük oranda tamamladıktan sonra 1930 sonrası dış politikasına ağırlık vererek politikasını Mustafa Kemal Atatürk'ün "Yurtta Sulh Cihanda Sulh" ilkesi üzerine geliștirmiştir. Türk dış politikasının ilkelerini Mustafa Kemal Atatürk belirlerken, uygulamasını ise Dışişleri Bakanı Tevfik Rüştü Aras gerçekleştirmiştir. Raporlarda da belirtildiği gibi Türkiye bu ilke doğrultusunda ülke güvenliğini sağlamak istemiştir.

Türkiye, 1933 yılı itibariyle daha etkili bir dış politika izleme yoluna giderek diğer devletlerle olan ilişkilerini güçlendirmek istemiştir. Sovyetler Birliği ile olan ilişkilerinin yanı sıra Batı ülkeleri ile olan ilişkilerinde de yakınlaşma sağlayarak bir denge politikası izleme yoluna gitmiștir. Türkiye’nin I. Dünya Savașı'nda yașamış olduğu tecrübeler, tek taraflı bir dış politika uygulamadan uzak durmasını sağlamıştır. Dolayısıyla özellikle İngiltere ile olan ilişkilerine dikkat etmiş ve bu ülke ile yakınlaşma siyaseti uygulamıştır. 1932 yılında dahil olduğu Milletler Cemiyeti ile olan münasebetleri de İngiltere ile olan ilişkileri çerçevesinde şekillenmiştir. Milletler Cemiyeti'nin Musul konusunda vermiş olduğu kararın İngiltere ile olan ilişkilerini kesintiye uğratmış olması sebebiyle cemiyete karşı mesafeli bir tavır takınmış olan Türkiye'nin öncelikli amacı özellikle kendisi ile ilgili kararlar alınırken bu görüşmelerin dışında tutulmamasını sağlamak olmuştur. 1935 yılı itibariyle, İtalya'nın yayılmacı politikası karşısında İngiltere ile daha yakın ilişkiler geliștirmiş ve Milletler Cemiyeti politikalarını da benimseyerek bu politikaların önde gelen savunucularından olmuştur.

Türkiye imzalamış olduğu paktlar ile kendi sınırlarını güvenlik altına almayı amaçlarken aynı zamanda kolektif bir barıștan yana olduğunu göstermiştir. Türkiye'nin barış yanlısı politikası İngiltere ile yakınlaşmasını ve uluslararası konularda daha etkin olmasını sağlamıştır. Türkiye imzalamış olduğu paktlarda İngiltere ile fikir alışverişi yaparak uluslararası meselelerde tek başına bir karar alma niyetinde olmadığını göstermiştir. Türkiye, 1934 Balkan Paktı ve 1937 Sadabad Paktı ile komşularıyla iyi ilişkiler geliștirirken Sadabad Paktı'nda yer alan ülkelerin sınır problemlerinin çözümünde almış olduğu inisiyatif ile kendi içine kapanık bir ülke olmadığını dünyaya göstermiştir. İngiltere ise Sadabad Paktı'nda direk yer almamış ancak paktın oluşumunu desteklemiştir. İngiltere'nin hesaplarında kurulacak olan paktı gerektiğinde Ortadoğu'nun güvenliği için kullanabilme düşünceleri mevcuttu. Dolayısıyla, daha önce Türkiye'nin ortaya attığı Ortadoğu Paktı fikrine sıcak bakmayan İngiltere bölgede köprü olabilme konumuna sahip olan Türkiye ile iyi ilişkileri çerçevesinde 1937 yılında bölgede bir pakt oluşmasına katkı sağlamıştır.

1933 sonrası Almanya ile İtalya'nın silahlanma ve yayılmacı politikası karşısında Türkiye'nin barıștan yana tavır almış olması, yayılmacı bir amacının olmadığını göstergesi olmuştur. 1935 yılı itibariyle İtalya'nın Habeșistan'ı işgal etmesi dolayısıyla İngiltere ile daha da yakınlaşması, Türkiye'nin dıș politikasında kaymalar yaşanacağının göstergesi olmuştur. 1935 öncesi Sovyet Rusya ile daha yakın ilişkiler içerisinde olan ve dıș politikasını 
Sovyet Rusya’yı göz önünde bulundurarak şekillendiren Türkiye, 1935 sonrası İngiltere ile yakınlaşma yaşarken dış politikasının șekillenmesinde bu ülkenin ağırlığı olmaya başlamıștır.

1933 yılı itibariyle Lozan Boğazlar Sözleşmesi'nde alınan kararlardan memnun olmadığını dile getirmeye başlayan Türkiye, 1933 Silahsızlanma Konferansı'nda ve 1934 Milletler Cemiyeti Konseyi'nde boğazların statüsünün yeniden gözden geçirilmesi gerektiği hususu üzerinde durmuştur. Ancak bu konuda İngiltere'den istediği desteği alamayan Türkiye, 1935 yılında İtalya'nın Habeşistan işgal etmesi ve Akdeniz'de bir tehdit oluşturması sonrasında isteklerini kabul ettirecek bir ortam bulmuştur. İtalya'nın Akdeniz'de yayılma politikası, İngiltere'nin de çıkarlarına aykırı bir durum oluşturduğundan, İngiltere, Türkiye ile daha yakın ilişkiler kurmaya başlamış ve boğazların statüsünde değişiklik talebine de olumlu yaklaşarak 1936'da Türkiye'nin boğazlar için bir konferansın toplanması isteğiyle gönderdiği notaya ilk olumlu cevabı veren ülke olmuştur. Türkiye, İtalyan tehdidiyle İngiltere ile ortak çıkarlarının oluşmasını değerlendirerek fırsatları lehine kullanabilen bir politika izlemiștir.

Türkiye, 1933-1937 döneminde dünyada meydana gelen gelişmelere izleyici kalmaktansa, inisiyatif alarak belirleyici bir politika uygulamıștır. Dış politikasını geçmişte yașamıș olduğu tecrübelerden ders çıkararak yönlendirmiștir. Uluslararası konularda alınacak kararlarda kendisinin de olması gerektiğini diğer ülkelere belirten Türkiye, bu süreçte meydana gelen olayları lehine çevirmeyi başarmış ve barıştan yana bir tavır takındığını vurgulamıştır.

\section{Kaynakça}

-Aleksandr Kolesnikov, Atatürk Dönemi Türk-Rus İlişkileri, Atatürk Araştırma Merkezi, Ankara 2010

-Ali Balcı, Türkiye Dış Politikası İlkeler, Aktörler, Uygulamalar, Etkileșim Yayınları, İstanbul 2013

-Arzu Al, Türk Dıș Politikası 1918-1980, Kaknüs Yayınları, 2014 İstanbul

-Atilla Sandıklı, Atatürk'ün Dış Politika Stratejisi: Hedefler ve Prensipler, Bilgesam Yayınları, İstanbul 2014

-Figen Atabey, “Türk-İngiliz Siyasi İlişkileri (1936-1939), History Studies International Journal Of History, Mart 2015, ss. 25-45

-Füsun Türkmen, Kırılgan İtttifaktan "Model Ortaklığa” Türkiye ABD İlişkileri, Timaş Yayınlarl, İstanbul 2012

- Hikmet Özdemir, Atatürk'ün Ardından Sir Percy Loraine'in Tanıklığı, Remzi Kitabevi, İstanbul 2010

-Mehmet Gönlübol-Cem Sar, Atatürk ve Türkiye'nin Dış Politikası (1919-1938), Atatürk 
Araştırma Merkezi, 2013 Ankara

-İsmail Soysal, “Türkiye’nin Batı İttifakına Yönelişi (1934-1937)”, Belleten, Sayı. 177, 1982, ss. 95-155

-Ludmila Jivkova, İngiliz-Türk İlişkileri 1933-1939, Çev: F. Muharrem-F. Erdinç, Habora Kitapevi, İstanbul 1978

-Mustafa Yılmaz, "İngiliz Büyükelçiliği Yıllık Raporlarında Türkiye (1935-1938)”, Beşinci Uluslararası Atatürk Kongresi, Atatürk Araștırma Merkezi, Cilt 1, 8-12 Aralık, 2003, ss. 635646

- PRO, FO, 371/17959, E 596/596/44

- PRO, FO, 371/19037, E 854/854/44

- PRO, FO, 371/20091, E 933/933/44

- PRO, FO, 371/20866, E 823/823/44

- PRO, FO, 371/21935, E 2214/2214/44

-Saime Yüceer, "Atatürk Dönemi (1919-1938) Türk-Rus İlişkilerinin Siyasi Boyutu", Atatürk'ten Soğuk Savaș Dönemine Türk-Rus İlişkileri, Atatürk Araștırma Merkezi, I. Çalıștay Bildirileri Ankara, 14-15 Mayıs, 2010, ss. 61- 107

-Şayan Ulusan, “Türkiye’nin Milletler Cemiyeti’ne (Cemiyet-i Akvam) Giriși Öncesi ve Sonrası", ÇTTAD, VII/16-17, 2008 Bahar-Güz, s. 237-258

-Tevfik Rüștü Aras, Atatürk'ün Dış Politikası, Kaynak Yayınları, İstanbul 2010

-Yuluğ Tekin Kurat, “Elli Yıllık Cumhuriyetin Dış Politikası (1923-1973)”, Belleten, Sy.154, 1975, ss. 265-308 